慶應義塾大学学術情報リポジトリ

Keio Associated Repository of Academic resouces

\begin{tabular}{|c|l|}
\hline Title & $\begin{array}{l}\text { Carboxylation of cyclohexanone with carbon dioxide and potassium phenoxide. dependence of } \\
\text { the reaction upon the amount of carbon dioxide complexed with potassium phenoxide }\end{array}$ \\
\hline Sub Title & \\
\hline Author & $\begin{array}{l}\text { 森, 久和(Mori, Hisakazu) } \\
\text { 佐竹, 由紀子(Satake, Yukiko) }\end{array}$ \\
\hline Publisher & 共立薬科大学 \\
\hline Publication year & 1985 \\
\hline Jtitle & $\begin{array}{l}\text { 共立薬科大学研究年報 (The annual report of the Kyoritsu College of } \\
\text { Pharmacy). No.30 (1985. ),p.112-112 }\end{array}$ \\
\hline JaLC DOI & \\
\hline Abstract & \\
\hline Notes & 抄録 \\
\hline Genre & Technical Report \\
\hline URL & $\begin{array}{l}\text { https://koara.lib.keio.ac.jp/xoonips/modules/xoonips/detail.php?koara_id=AN00062898-0000003 } \\
\text { 0-0112 }\end{array}$ \\
\hline
\end{tabular}

慶應義塾大学学術情報リポジトリ(KOARA)に掲載されているコンテンツの著作権は、それぞれの著作者、学会または出版社/発行者に帰属し、その権利は著作権法によって 保護されています。引用にあたっては、著作権法を遵守してご利用ください。

The copyrights of content available on the KeiO Associated Repository of Academic resources (KOARA) belong to the respective authors, academic societies, or publishers/issuers, and these rights are protected by the Japanese Copyright Act. When quoting the content, please follow the Japanese copyright act. 


\title{
Carboxylation of Cyclohexanone with Carbon Dioxide and Potassium Phenoxide. Dependence of the Reaction upon the Amount of Carbon Dioxide Complexed with Potassium Phenoxide*
}

\author{
Hisakazu Mori and Yukiko SATAKE
}

森 久和, 佐竹由紀子

The uptake of $\mathrm{CO}_{2}$ by potassium phenoxide ( $\mathrm{PhOK}$ ) in $\mathrm{N}, \mathrm{N}$-dimethylformamide (DMF) was investigated in a vacuum system. Further, the carboxylation of cyclohexanone by various amounts of $\mathrm{CO}_{2}$ complexed with $\mathrm{PhOK}$ was studied. The yield of the carboxylate at $30 \mathrm{~s}$ increased with the increase of M.R. (molar ratio of $\mathrm{CO}_{2}$ absorbed by $\mathrm{PhOK}$ to PhOK initially added) in the range of M.R. less than 0.41 . However, in the range of M.R. above 0.60 , it decreased with increase of M. R. The time required for completion of the reaction depended on the M.R., and three ranges were distinguishable. The ultimate yield of the carboxylate in the carboxylation increased proportionally to $M$. $R$. value. It is considered that the source of $\mathrm{CO}_{2}$ for carboxylate formation was $\mathrm{CO}_{2}$ complexed with $\mathrm{PhOK}$ rather than uncomplexed $\mathrm{CO}_{2}$.

* 本報告は Chem. Pharm. Bull., 33, 3469-3472（1985）に発表 